\title{
Subclinical hypocalcemia, plasma biochemical parameters, lipid metabolism, postpartum disease, and fertility in postparturient dairy cows
}

\author{
W. G. Chamberlin, ${ }^{\star} \dagger$ J. R. Middleton, $\nmid \ddagger^{1}$ J. N. Spain, ${ }^{*}$ G. C. Johnson, $¥ \S$ M. R. Ellersieck,\# and P. Pithua $†$ \\ *Department of Animal Sciences, \\ †Department of Veterinary Medicine and Surgery, \\ ‡Department of Veterinary Pathobiology, \\ $\S$ Veterinary Medical Diagnostic Laboratory, and \\ \#Department of Statistics, University of Missouri, Columbia 65211
}

\section{ABSTRACT}

A study was conducted to evaluate the potential association between Ca status at calving and postpartum energy balance, liver lipid infiltration, disease occurrence, milk yield and quality parameters, and fertility in Holstein cows. One hundred cows were assigned to 1 of 2 groups based on whole-blood ionized Ca concentration $([\mathrm{iCa}])$ on the day of calving $[\mathrm{d} 0$; hypocalcemic $[\mathrm{iCa}]<1.0 \mathrm{mmol} / \mathrm{L}(\mathrm{n}=51)$; normocalcemic $[\mathrm{iCa}] \geq 1.0$ $\mathrm{mmol} / \mathrm{L}(\mathrm{n}=49)]$. Cows were blocked based on calving date and parity. Blood samples were collected approximately $14 \mathrm{~d}$ from expected calving date $(\mathrm{d}-14)$, the day of calving ( $\mathrm{d} 0$ ), and on $\mathrm{d} 3,7,14,21$, and 35 postpartum for measurement of plasma nonesterified fatty acid, iCa, total $\mathrm{Ca}$, glucose, and total and direct bilirubin concentrations, and plasma aspartate aminotransferase and gamma glutamyl transferase activities. Liver biopsies were obtained from a subset of cows on d 0,7 , and 35 for quantification of lipid content. Milk samples were collected on d 3, 7, 14, 21, and 35 postpartum for measurement of somatic cell count and percentages of protein, fat, and solids-not-fat. Data for peak test-day milk yield, services per conception, and days open were obtained from Dairy Herd Improvement Association herd records. Disease occurrence was determined based on herd treatment records. Hypocalcemic cows had significantly higher nonesterified fatty acids on d 0. Hypocalcemic cows also had significantly more lipid in hepatocytes on $\mathrm{d} 7$ and 35 postpartum. However, no statistically significant differences were observed between groups for plasma aspartate aminotransferase and gamma glutamyl transferase activities or total and direct bilirubin concentrations. Milk protein percentage was lower in hypocalcemic cows on d 21 and 35 . However other milk quality variables (somatic cell count, milk fat percentage, and solids-not-fat) and

Received April 5, 2013.

Accepted August 7, 2013.

${ }^{1}$ Corresponding author: middletonjr@missouri.edu milk yield variables (peak test-day milk yield and 305d mature-equivalent $4 \%$ fat-corrected milk yield) did not differ between groups. No differences were observed between groups in the occurrence of clinical mastitis, ketosis, displaced abomasum, dystocia, retained placenta, metritis, or fertility measures (percentage cycling at 50-60 d postpartum, services per conception, or days open). These data suggest that early lactation fatty acid metabolism differs between cows with subclinical hypocalcemia and their normocalcemic counterparts.

Key words: subclinical hypocalcemia, negative energy balance, transition cow

\section{INTRODUCTION}

Hypocalcemia is a metabolic disorder in which homeostatic mechanisms fail to maintain normal blood $\mathrm{Ca}$ concentrations at the onset of lactation (Goff and Horst, 1997a). Whereas the incidence of clinical milk fever in the United States is approximately $5 \%$ (McLaren et al., 2006), it is reported that as many as $50 \%$ of periparturient dairy cows may suffer from subclinical hypocalcemia (Horst et al., 2003; Reinhardt et al., 2011) with total blood Ca concentrations being between 1.38 and $2.0 \mathrm{mmol} / \mathrm{L}$ (5.5 and $8.0 \mathrm{mg} /$ dL; Goff, 2008). Prevention of milk fever and its consequences have been the focus of much research in the past (Lean et al., 2006). However, the associations of subclinical hypocalcemia, lipid metabolism, and health have received less attention.

Dairy cows may mobilize fat during the transition period if an energy deficit exists due to an imbalance of energy requirements versus intake. However, the degree of fat mobilization and whether the cow goes into a negative energy balance varies from cow to cow (Bell, 1995; Grummer, 1995; Goff, 2006; Khan et al., 2013; Rocco and McNamara, 2013; Weber et al., 2013). The hallmark of the dairy cow's negative energy balance is mobilizing fat from body stores as NEFA to utilize for energy. Monitoring NEFA during the prepartum period provides the most utility for predicting future events, 
as it has been significantly associated with increased risk of developing displaced abomasum (LeBlanc et al., 2005), retained placenta (LeBlanc et al., 2004), and culling (Duffield et al., 2009). Postpartum monitoring of BHBA is often more reflective of a pathologic negative energy balance and has been associated with increased risk for developing displaced abomasum (LeBlanc et al., 2005), decreased probability of pregnancy after the first service (Walsh et al., 2007), decreased milk production (Duffield et al., 2009), and increased risk for culling (Seifi et al., 2011). Periparturient lipid-related disorders associated with elevated NEFA and BHBA levels include ketosis and fatty liver disease (Grummer, 1993).

Recently, focus has increased on the relationships between multiple postpartum disorders in dairy cows, as these disorders appear to have common factors influencing their occurrence. Some of the early research that investigated the relationship between multiple diseases showed that cows experiencing milk fever were almost 9 times more likely to exhibit signs of ketosis compared with cows not developing milk fever (Curtis et al., 1983). Clinical hypocalcemia has also been associated with increased risk of developing several other common postpartum diseases, such as mastitis, retained placenta, metritis, and displaced abomasum (Curtis et al., 1983; Goff and Horst 1997b; Mulligan et al., 2006; Goff, 2008). Similarly, in more recent work, cows with subclinical hypocalcemia were at greater risk of developing metritis (Martinez et al., 2012). In contrast, Chapinal et al., (2011) noted that subclinical hypocalcemia in the first week postpartum was not associated with retained placenta or metritis, but was associated with an increased risk of developing a displaced abomasum. Other work has associated subclinical hypocalcemia with increased plasma NEFA concentrations (Horst et al., 2003; Spain et al., 2004; Reinhardt et al., 2011; Martinez et al., 2012), but did not further investigate the relationship between the 2 disorders. Hence, more research focusing on subclinical hypocalcemia and its relationship with lipid metabolism and clinical disease occurrence is warranted. The objectives of this study were to evaluate potential associations between blood Ca concentrations at calving and plasma biochemical parameters, lipid metabolism, postpartum disease occurrence, milk production and quality, and fertility in postparturient multiparous Holstein cows.

\section{MATERIALS AND METHODS}

\section{Study Design}

One hundred multiparous Holstein dairy cattle were studied over a 2-yr period. All procedures were ap- proved by the University of Missouri Animal Care and Use Committee (Columbia). Cows were enrolled longitudinally over the $2 \mathrm{yr}$ and grouped at calving based on whole-blood ionized Ca concentrations ([iCa]) into 2 groups: (1) hypocalcemic cows $(\mathrm{n}=51 ;[\mathrm{iCa}]<1.0$ $\mathrm{mmol} / \mathrm{L}$ ) and (2) normocalcemic cows $(\mathrm{n}=49$; [iCa] $\geq 1.0 \mathrm{mmol} / \mathrm{L}$ ). The only multiparous cow not enrolled in the study over the 2 -yr period was a cow that succumbed to clinical milk fever and thus required treatment. Cows were housed at the University of Missouri Foremost Dairy Research Center (Columbia), and were fed a balanced dry cow ration free of anionic salts from the day of dry-off until the day of calving (Table 1). All cows were fed the same lactating cow diet formulation during the postpartum portion of the study (Table 1).

\section{Sample and Data Collection}

Blood samples were collected via coccygeal venipuncture from each cow into heparinized tubes (Vacutainer; Becton Dickinson Vacutainer Systems, Franklin Lakes, NJ) at $14 \mathrm{~d}$ from expected calving date $(-14)$, the day of calving (0), and on d $3,7,14,21$, and 35 postpartum between 1400 and $1600 \mathrm{~h}$ for measurement of wholeblood [iCa], plasma biochemical parameters, and plasma NEFA concentration. Milk samples were collected during the afternoon milking on d $3,7,14,21$, and 35 postpartum using an in-line sampler (Westfalia-Surge Inc., Naperville, IL) into vials containing a 2-bromo2-nitropropane-1,3-diol preservative tablet (Broad Spectrum Microtabs II; D \& F Control Systems Inc., Dublin, CA) for determination milk protein percentage, fat percentage, SNF percentage, and SCC (Mid-South Dairy Records, Springfield, MO).

To assess the extent of fat mobilization into the liver, liver biopsies were obtained from a subset of 24 cattle in yr 1 and 22 cattle in yr 2 on the day of calving and on d 7 and 35 postpartum. Cattle for liver biopsies were the first cows to calve in a given year that could be paired (blocked) based on parity, calving date, and group assignment. Liver tissue was obtained via percutaneous biopsy using a large-bore biopsy needle similar to that described by Hughes (1962). Briefly, a $5 \times 5-\mathrm{cm}$ area over the 10th or 11th intercostal space intersecting a diagonal line between the point of the olecranon and the tuber coxae on the right side of the cow was clipped of hair and aseptically prepared. The subcutaneous tissue and intercostal muscle were anesthetized by local infiltration with $10 \mathrm{~mL}$ of $2 \%$ lidocaine. A \#22 scalpel blade was used to make an incision in the skin and the biopsy needle was guided through the skin, subcutaneous tissues, intercostal muscle, peritoneum, and liver capsule to obtain a core of liver tissue. Liver tissue 
Table 1. Composition and chemical analyses of the 2 dry cow diets and the lactating cow diet

\begin{tabular}{|c|c|c|c|}
\hline Item & $\begin{array}{l}\text { Dry cow diet } \\
(\text { remainder of study) })^{1}\end{array}$ & $\begin{array}{c}\text { Dry cow diet } \\
\text { (first } 18 \text { dry cows) }^{1}\end{array}$ & $\begin{array}{l}\text { Lactating cow diet } \\
\text { (all cows) }\end{array}$ \\
\hline \multicolumn{4}{|l|}{ Ingredient (\%; DM basis) } \\
\hline Grass hay & 20.9 & 20.9 & 1.7 \\
\hline Alfalfa hay & - & - & 13.1 \\
\hline Alfalfa silage & - & - & 11.8 \\
\hline Corn silage & 33.9 & 33.9 & 20.9 \\
\hline Ground corn & 10.3 & 10.3 & 21.6 \\
\hline Soybean meal, $48 \%$ & 7.5 & 7.5 & 5.4 \\
\hline Whole cottonseed & - & - & 10.1 \\
\hline Roasted soybeans & - & - & 3.9 \\
\hline Wet brewers grains & - & - & 3.5 \\
\hline Soy hulls & 26.8 & 26.8 & 6.0 \\
\hline Vitamin/mineral premix & $0.64^{1}$ & $0.64^{1}$ & 2.0 \\
\hline \multicolumn{4}{|c|}{ Chemical analysis (\%; DM basis) } \\
\hline DM & 50.2 & 53.3 & 53.7 \\
\hline $\mathrm{CP}$ & 14.89 & - & 17.9 \\
\hline $\mathrm{ADF}$ & 32.74 & - & 23.47 \\
\hline $\mathrm{NDF}$ & 49.32 & - & 33.27 \\
\hline $\mathrm{Ca}$ & 0.68 & 0.89 & 0.95 \\
\hline $\mathrm{P}$ & 0.31 & 0.35 & 0.48 \\
\hline $\mathrm{Mg}$ & 0.20 & 0.22 & 0.23 \\
\hline $\mathrm{K}$ & 1.68 & 1.41 & 1.57 \\
\hline $\mathrm{S}$ & 0.14 & 0.16 & 0.20 \\
\hline $\mathrm{Na}$ & 0.10 & 0.16 & 0.25 \\
\hline $\mathrm{Cl}$ & 0.32 & 0.47 & 0.45 \\
\hline DCAD $(\mathrm{mEq} / 100 \mathrm{~g})$ & +33.67 & +25.37 & \\
\hline
\end{tabular}

${ }^{1}$ The first 18 dry cows were inadvertently fed the lactating vitamin/mineral premix. The remaining dry cows were fed the correct dry cow vitamin/mineral premix. Composition of the dry cow premix was as follows: $79.2 \%$ ground corn, $1.7 \%$ salt, $1 \%$ vitamin ADE mix, $2.3 \%$ vitamin E, $0.4 \%$ trace mineral pack, $4.4 \%$ choline, $0.15 \%$ monensin, $4 \%$ yeast, $0.35 \%$ zinc methionine, and $6.6 \%$ biotin. Composition of the lactating cow premix was as follows: $28 \%$ ground corn, $7.5 \%$ salt, $7.5 \%$ potassium sulfate/magnesium sulfate, $2.5 \%$ vitamin ADE mix, $2.5 \%$ vitamin E, $1.5 \%$ trace mineral pack, $15 \%$ dicalcium phosphate, $17.5 \%$ limestone, $6 \%$ yeast, $10 \%$ biotin, $0.2 \%$ monensin, $0.5 \%$ zinc methionine, and $1.25 \%$ sodium bicarbonate. Cells with "—" indicate not applicable or no data available.

samples were fixed in $10 \%$ neutral buffered formalin and stored until analyzed.

The occurrence of postpartum disorders, including ketosis, displaced abomasum, retained placenta, metritis, clinical mastitis, and dystocia, were recorded from farm herd health records using definitions contained in the farm's standard operating procedures. These diseases were recorded as present or not present. Ketosis was diagnosed based upon a color change on a urine dip stick (Ketostix; Bayer AG, Leverkusen, Germany) equivalent to $15 \mu \mathrm{mol} / \mathrm{L}$ or greater of acetoacetate. Urine ketones were measured on d 0 to 14 of lactation as part of the farm's early-lactation cow monitoring program. Displaced abomasum was diagnosed when surgical correction was performed by a veterinarian. Retained placenta was diagnosed when the fetal membranes failed to be completely expelled from the birth canal within $12 \mathrm{~h}$ of parturition (Sheldon et al., 2006). Metritis was defined as a cow with a fever (rectal temperature $>39.4^{\circ} \mathrm{C}$ ) and a discolored, foul-smelling uterine discharge (Sheldon et al., 2006) diagnosed by farm personnel during daily cow checks on d 0 to 14 of lactation. Per farm protocol, clinical mastitis cases were recorded when a cow was treated with intramammary antibiotics. The farm protocol dictates that any cow with abnormalities in milk secretion, such as clots, strings, or alterations in milk color, with or without visible or palpable inflammatory changes in the mammary tissue, be treated with intramammary antibiotics at first occurrence. Dystocia was scored by farm personnel from 1 to 5 , with 1 being no assistance, 2 being assistance required but pulled by 1 person, 3 being assistance required by 2 or more people, 4 being mechanical assistance needed, and 5 being surgical intervention (Lombard et al., 2007).

Peak test-day milk yield was obtained from herd DHIA records (Mid-South Dairy Records). Estimated 305-d mature-equivalent 4\% FCM yield was based on the test-day milk weight closest to 60 DIM obtained from herd DHIA records using the equation $4 \% \mathrm{FCM}$ $=(0.4 \times \mathrm{kg}$ of mature-equivalent milk $)+(15 \times \mathrm{kg}$ of mature-equivalent milk fat) (NRC, 2001). The milk production parameters were only assessed for cows that were still in the herd at the test day closest to 60 DIM $(\mathrm{n}=92)$.

Fertility measurements included services per conception, days open, and cyclicity at 50 to $60 \mathrm{~d}$ postpartum. 
Services per conception and days open were obtained from herd DHIA records. Cyclicity was measured via transrectal ultrasound examination of the ovaries at 50 to $60 \mathrm{~d}$ postpartum by a board-certified theriogenologist. Cows were not considered to be cycling unless there was evidence of a corpus luteum on one or both ovaries (Peter et al., 2009).

\section{Laboratory Methods}

Within 30 min of sample collection, whole-blood [iCa] was determined using a portable blood chemistry analyzer (VetStat; IDEXX Laboratories Inc., Westbrook, ME). Plasma was separated from blood cells by centrifugation at $2,100 \times g$ for $15 \mathrm{~min}$ at $4^{\circ} \mathrm{C}$ (RC3B Plus centrifuge; Sorvall Instruments, Newtown, CT). Samples for plasma biochemical analysis were refrigerated overnight and taken to the University of Missouri Veterinary Medical Diagnostic Laboratory for determination of plasma biochemical parameters using an automated biochemistry analyzer (Olympus AU400; Olympus Corp., Tokyo, Japan). Biochemical parameters of interest included plasma total $\mathrm{Ca}$, glucose, total bilirubin, and direct bilirubin concentrations and gamma glutamyl transferase (GGT) and aspartate aminotransferase (AST) activities.

Remaining plasma samples were frozen $\left(-20^{\circ} \mathrm{C}\right)$ and used for measurement of plasma NEFA concentration at the end of each study year. A NEFA C kit (Wako Chemicals USA Inc., Richmond, VA) was used for measurement of NEFA concentration according to the procedures of Johnson and Peters (1993).

Formalin-fixed liver biopsy specimens were longitudinally bisected and paraffin embedded for staining. Sections of tissue were stained with oil red $\mathrm{O}$ to detect lipid. Lipid content of 6 randomly selected areas of each specimen were assessed to determine the ratio of oil red O stained to total tissue surface area as described by Sevinç et al. (2003) and Semecan and Sevinç (2005). This was done by taking digital images and counting the number of pixels that were stained red for lipid and dividing by the total number of pixels that stained blue for tissue and multiplying by 100 to yield liver lipid percentage.

\section{Data Analysis}

Cows were blocked based on parity and calving date for analysis. Based on timing of calving, second-parity cows were blocked with second- or third-parity cows. Cows greater than third parity were blocked with any third-or-greater-parity cows. Cows in a given block had to be of the appropriate parity as outlined above and within $24 \mathrm{~d}$ of calving from each other. Twenty-four days allowed for including the maximum number of cows in a given block, while decreasing the influence of external variables, such as changes in ambient temperature and humidity.

Univariate ANOVA was performed for repeated measures using PROC MIXED of SAS (SAS Institute Inc., Cary, NC), which performed an F-test with $\alpha=0.05$. The model used was $\mathrm{Y}_{\mathrm{ijk}}=\mu+\alpha_{\mathrm{i}}+\beta_{\mathrm{j}}+\gamma_{\mathrm{k}}+(\alpha \gamma)_{\mathrm{ik}}$ $+(\alpha \beta)_{\mathrm{ij}}$, where $\mathrm{Y}=$ whole-blood iCa, plasma total $\mathrm{Ca}$, NEFA, glucose, total bilirubin, direct bilirubin, indirect bilirubin, AST, GGT, milk components, services per conception, days open, or liver lipid percentage; $\alpha=\mathrm{Ca}$ status at calving; $\mathrm{i}=1$ or $2 ; \beta=$ block; $\mathrm{j}=1, \ldots, 67 ; \gamma$ $=$ day relative to calving; $\mathrm{k}=-14,0,3,7,14,21$, or 35 ; $\alpha \gamma=$ interaction between Ca status and day relative to calving; and $\alpha \beta=$ interaction between Ca status and block (error term). For variables that met equality of variances assumption, but failed to meet the normal distribution assumption (NEFA, total bilirubin, GGT, and liver lipid percentage), a rank transformation was performed based on the work of Conover and Iman (1981) and then analyses were performed as detailed above. All other data met the assumptions of equality of variance and normality.

Using PROC CORR in SAS, significant correlations $(P<0.05)$ between any of the continuous variables were found, and those variables with a significant correlation that were pertinent to our hypothesis were chosen for further analysis by stepwise regression. Stepwise regression was performed using PROC REG of SAS to compare plasma NEFA concentration to lipid percentage in hepatocytes or indirect bilirubin. The maximum model used was $\mathrm{Y}=\beta_{0}+\beta_{1} \mathrm{x}_{1}+\beta_{2} \mathrm{x}_{2}+\beta_{3} \mathrm{x}_{3}+\ldots+$ $\beta_{7} \mathrm{x}_{7}$, where $\mathrm{Y}=$ liver lipid percentage on $\mathrm{d} 0,7$, or 35 or indirect bilirubin on $\mathrm{d}-14,0,3,7,14,21$, or $35 ; \mathrm{x}_{1}$ $=$ NEFA $d-14 ; x_{2}=$ NEFA d $0 ; x_{3}=$ NEFA d $3 ; x_{4}$ $=$ NEFA d $7 ; x_{5}=$ NEFA d $14 ; x_{6}=$ NEFA d $21 ;$ and $\mathrm{x}_{7}=\mathrm{NEFA} d$ 35. Ionized Ca concentration and total plasma $\mathrm{Ca}$ concentration on d 0 were compared with NEFA, liver lipid percentage, and indirect bilirubin. When comparing iCa and total plasma Ca to NEFA, liver lipid concentration, and indirect bilirubin concentration, the maximum model was $\mathrm{Y}=\beta_{0}+\beta_{1} \mathrm{x}_{1}+\beta_{2} \mathrm{x}_{2}$ $+\beta_{3} \mathrm{x}_{3}+\ldots+\beta_{11} \mathrm{x}_{11}$. In this model, $\mathrm{Y}=\mathrm{iCa}$ or total plasma Ca concentration on d $0, \mathrm{x}_{1}=$ NEFA d $-14, \mathrm{x}_{2}$ $=$ NEFA d 0, $x_{3}=$ NEFA d 3, $x_{4}=$ NEFA d $7, x_{5}=$ NEFA d $14, x_{6}=$ NEFA d $21, x_{7}=$ NEFA d $35, x_{8}=$ liver lipid d $0, x_{9}=$ liver lipid d 7, $x_{10}=$ liver lipid d 35, and $\mathrm{x}_{11}=$ indirect bilirubin $\mathrm{d} 0$. Inclusion criteria for each model were $P \leq 0.10$ to enter the model and $P \leq$ 0.05 to stay in the model.

Binomial parameters such as disease occurrence and cyclicity were analyzed using PROC GLIMMIX of SAS. The model used was $Y_{\mathrm{ijk}}=\mu+\alpha_{\mathrm{i}}+\beta_{\mathrm{j}}+(\alpha \beta)_{\mathrm{ij}}$, 
where $\mathrm{Y}=$ ketosis, dystocia, retained placenta, metritis, mastitis, displaced abomasum, or cyclicity; $\alpha=\mathrm{Ca}$ status at calving; $\mathrm{i}=1$ or $2 ; \beta=$ block; $\mathrm{j}=1, \ldots, 67$; and $\alpha \beta=$ interaction between Ca status and block (error term). For the purposes of data analysis, dystocia scores were combined to create a dichotomous outcome [i.e., no assistance (score 1) or assistance (combined scores 2-5)].

\section{RESULTS}

During the first 3 mo of the study, dry cows were inadvertently fed a diet containing a vitamin and mineral premix balanced for lactating cows, with a higher $\mathrm{Ca}$ concentration than the dry cow vitamin and mineral premix (Table 1). Any variation caused by this mistake was accounted for by blocking cattle based on calving date and putting those cows fed the same diet together in a block. A total of 67 blocks were used for data analysis, 33 of which were complete with 2 cows per block, and 34 of which were incomplete with 1 cow per block (18 hypocalcemic and 16 normocalcemic cows).

The actual time from first sampling $(-14)$ to calving was $15.7 \pm 3.8 \mathrm{~d}$ for hypocalcemic cows and $15.2 \pm$ $3.1 \mathrm{~d}$ for normocalcemic cows $(P=0.24)$. The parity of hypocalcemic cows $(3.5 \pm 1.5$; mean $\pm \mathrm{SD})$ was greater than normocalcemic cows $(2.8 \pm 1.4 ; P=0.02)$. As expected, on the day of calving, whole-blood [iCa] were lower for hypocalcemic cows than normocalcemic cows $(P<0.01$; Figure 1a). Similarly, plasma total Ca concentrations were lower for hypocalcemic cows than normocalcemic cows $(P<0.01$; Figure 1b).

More normocalcemic than hypocalcemic cows (25 vs. 18) had liver biopsy samples by chance because as cows were calving farther apart, it was more difficult to obtain biopsies from cows in different groups that would fit in the same block. Additionally, 3 hypocalcemic cows initially had liver biopsies taken but were subsequently excluded from the data analysis. One was diagnosed with clinical milk fever and treated with $23 \%$ Ca borogluconate intravenously, and the other two did not have liver tissue in at least 1 sample based on histologic examination.

For the first 15 of the 100 cows enrolled in the study, milk protein percentage, fat percentage, and SNF percentage were not requested when the samples were submitted to the DHIA laboratory; only milk SCC concentrations were requested. Based on data from the remaining 85 cows, milk protein percentage was lower on d 21 and 35 for hypocalcemic cows than normocalcemic cows $(P=0.02)$. However, no differences were observed between groups in milk fat percentage, SNF percentage, linear SCS, and SCC (Table 2). Mean \pm standard deviation peak test-day milk yield was 48.0 a)

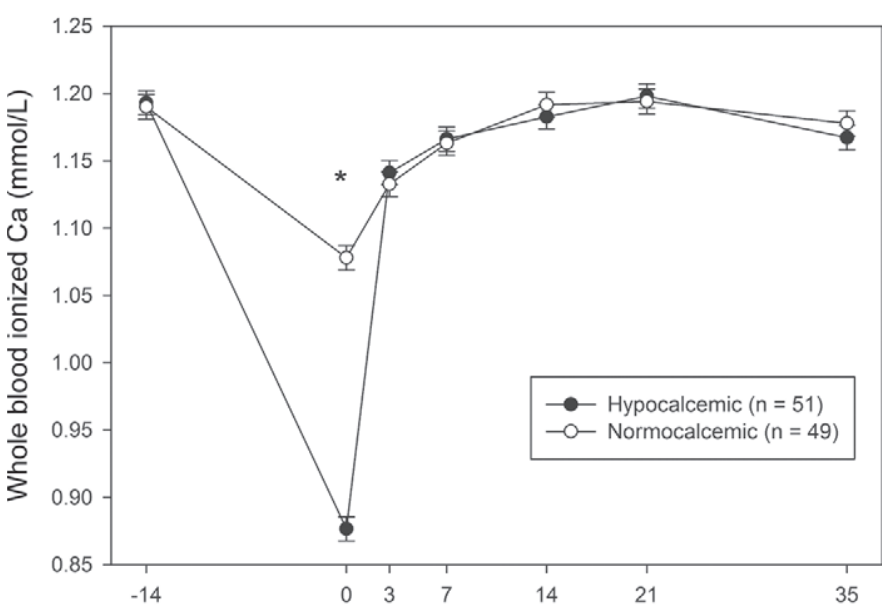

b)

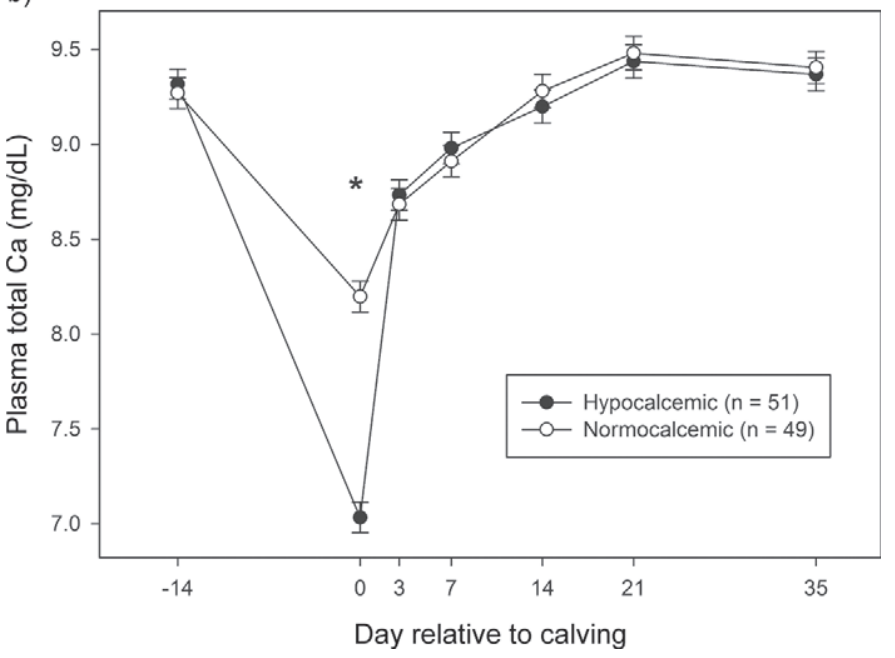

Figure 1. (a) Least squares means \pm SE for whole-blood ionized $\mathrm{Ca}$ concentration $(\mathrm{mmol} / \mathrm{L})$ versus day relative to calving by group $(* P<0.01)$. (b) Least squares means \pm SE for plasma total Ca concentration $(\mathrm{mg} / \mathrm{dL})$ versus day relative to calving by group $\left({ }^{*} P<\right.$ $0.01)$.

$\pm 6.2 \mathrm{~kg}$ in the hypocalcemic group and $46.6 \pm 6.5$ $\mathrm{kg}$ in the normocalcemic group $(P=0.86)$. Mean \pm standard deviation 305-d mature-equivalent $4 \%$ FCM yield was 10,207 $\pm 1,451 \mathrm{~kg}$ in the hypocalcemic group and $10,383 \pm 1,744 \mathrm{~kg}$ in the normocalcemic group $(P$ $=0.69)$.

Hypocalcemic cows had significantly higher mean plasma NEFA concentrations on d $0(P=0.02$; Figure 2) and tended to have higher mean plasma NEFA concentrations on d $21(P=0.06)$ compared with normocalcemic cows. Additionally, hypocalcemic cows had a higher liver lipid percentage on $\mathrm{d} 7$ and 35 than normocalcemic cows $(P \leq 0.02$; Figure 3$)$. There were no detectable differences in plasma glucose, total bilirubin, direct bilirubin, and indirect bilirubin concentrations, 
Table 2. Means and SD (in parentheses) for milk quality measures presented by group and day of study

\begin{tabular}{|c|c|c|c|c|c|c|c|c|c|c|}
\hline \multirow[b]{2}{*}{ Parameter $^{1}$} & \multicolumn{10}{|c|}{ Day of study ${ }^{2}$} \\
\hline & Нуро & Normo & Нуро & Normo & Нypo & Normo & Нуро & Normo & Нуро & Normo \\
\hline Milk fat $(\%)$ & $\begin{array}{c}5.1 \\
(1.4)\end{array}$ & $\begin{array}{c}4.7 \\
(1.4)\end{array}$ & $\begin{array}{c}3.8 \\
(1.4)\end{array}$ & $\begin{array}{c}4.9 \\
(1.4)\end{array}$ & $\begin{array}{c}3.8 \\
(1.3)\end{array}$ & $\begin{array}{c}4.3 \\
(1.5)\end{array}$ & $\begin{array}{c}3.9 \\
(1.4)\end{array}$ & $\begin{array}{c}4.0 \\
(1.5)\end{array}$ & $\begin{array}{c}3.8 \\
(1.4)\end{array}$ & $\begin{array}{c}3.5 \\
(1.3)\end{array}$ \\
\hline Milk protein (\%) & $\begin{array}{c}4.0 \\
(0.7)\end{array}$ & $\begin{array}{c}4.1 \\
(0.7)\end{array}$ & $\begin{array}{c}3.4 \\
(0.5)\end{array}$ & $\begin{array}{c}3.5 \\
(0.6)\end{array}$ & $\begin{array}{c}2.9 \\
(0.6)\end{array}$ & $\begin{array}{c}3.0 \\
(0.6)\end{array}$ & $\begin{array}{l}2.7^{\mathrm{a}} \\
(0.5)\end{array}$ & $\begin{array}{r}3.0^{b} \\
(0.6)\end{array}$ & $\begin{array}{r}2.6^{\mathrm{a}} \\
(0.5)\end{array}$ & $\begin{array}{r}2.8^{b} \\
(0.5)\end{array}$ \\
\hline Linear score SCC & $\begin{array}{l}3.8 \\
(2.4)\end{array}$ & $\begin{array}{c}4.3 \\
(2.4)\end{array}$ & $\begin{array}{c}3.3 \\
(2.3)\end{array}$ & $\begin{array}{l}3.8 \\
(2.4)\end{array}$ & $\begin{array}{l}2.7 \\
(2.3)\end{array}$ & $\begin{array}{l}3.1 \\
(2.2)\end{array}$ & $\begin{array}{c}2.5 \\
(2.3)\end{array}$ & $\begin{array}{c}2.8 \\
(2.3)\end{array}$ & $\begin{array}{l}2.4 \\
(2.2)\end{array}$ & $\begin{array}{c}3.1 \\
(2.2)\end{array}$ \\
\hline $\mathrm{SCC}($ cells $/ \mathrm{mL})$ & $\begin{array}{l}414 \\
(902)\end{array}$ & $\begin{array}{c}445 \\
(944)\end{array}$ & $\begin{array}{l}202 \\
(958)\end{array}$ & $\begin{array}{c}641 \\
(1,012)\end{array}$ & $\begin{array}{c}350 \\
(930)\end{array}$ & $\begin{array}{c}301 \\
(995)\end{array}$ & $\begin{array}{c}216 \\
(1,011)\end{array}$ & $\begin{array}{c}509 \\
(1,098)\end{array}$ & $\begin{array}{l}450 \\
(987)\end{array}$ & $\begin{array}{c}394 \\
(1,038)\end{array}$ \\
\hline
\end{tabular}

${ }^{a, b}$ Values within day with different superscripts differ from each other $(P \leq 0.02)$.

${ }^{1}$ No differences were detected between groups within day $(P \geq 0.20)$, with the exception of milk protein percentage on $\mathrm{d} 21$ and 35 , which was lower in hypocalcemic cows $(P \leq 0.02)$.

${ }^{2} \mathrm{Hypo}=$ hypocalcemic [whole-blood ionized Ca concentration $([\mathrm{iCa}])$ within $24 \mathrm{~h}$ postcalving $<1.0 \mathrm{mmol} / \mathrm{L} ; \mathrm{n}=51$ ]; Normo $=$ normocalcemic (whole-blood [iCa] within $24 \mathrm{~h}$ postcalving $\geq 1.0 \mathrm{mmol} / \mathrm{L} ; \mathrm{n}=49$ ). Note that the first day on which milk quality data were collected was d 3 .

or GGT and AST activities between hypocalcemic and normocalcemic cows at any of the measured time points before or after calving $(P \geq 0.22$; Table 3$)$.

The occurrence of ketosis, displaced abomasum, retained fetal membranes, metritis, mastitis, and dystocia did not differ between groups $(P \geq 0.14$; Table 4). Likewise, there were no detectable differences in the proportions of cows cycling by 50 to $60 \mathrm{~d}$ postpartum, services per conception, or days open between hypocalcemic and normocalcemic cows $(P \geq 0.36$; Table 5$)$. Days to first service also did not differ between groups

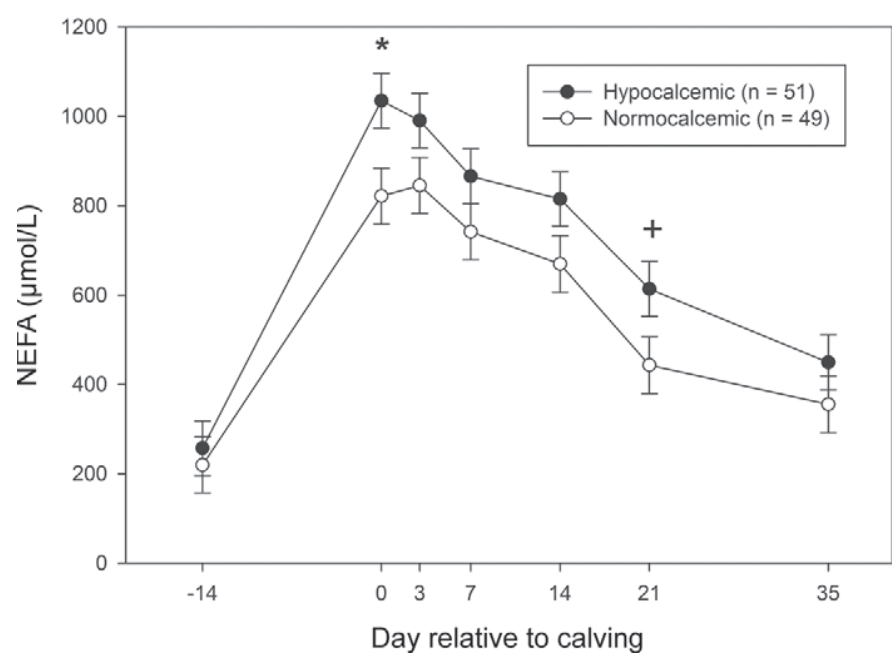

Figure 2. Least squares means \pm SE for plasma NEFA concentration $(\mu \mathrm{mol} / \mathrm{L})$ versus day relative to calving by group $(* P=0.02$; $+P=0.06)$. Whole-blood ionized Ca concentrations within $24 \mathrm{~h}$ after calving were $<1.0 \mathrm{mmol} / \mathrm{L}$ for hypocalcemic cows and $\geq 1 \mathrm{mmol} / \mathrm{L}$ for normocalcemic cows. (mean $\pm \mathrm{SD}$; hypocalcemic cows $=72 \pm 8.4$ d vs. normocalcemic cows $=71.3 \pm 9.4 \mathrm{~d} ; P=0.39)$.

Simple linear regression revealed an overall negative correlation between liver lipid percentage and plasma glucose concentration $(P<0.01 ; \mathrm{r}=-0.27)$. A significant positive correlation was detected between liver lipid percentage and AST activity $(P<0.01$; r $=0.41)$ and between plasma NEFA concentration and AST activity $(P<0.01 ; \mathrm{r}=0.26)$. Gamma glutamyl transferase activity was also significantly correlated with plasma NEFA concentration $(P=0.02 ; \mathrm{r}=0.09)$.

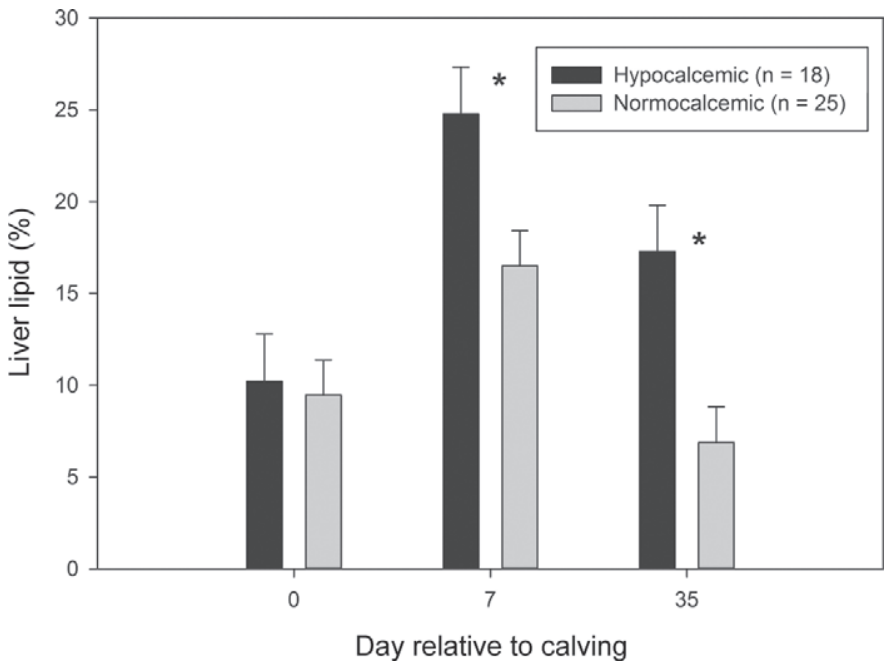

Figure 3. Least squares means $\pm \mathrm{SE}$ for liver lipid content determined by histologic evaluation (\% lipid) versus day relative to calving by group $\left({ }^{*} P \leq 0.02\right)$. Whole-blood ionized Ca concentrations within $24 \mathrm{~h}$ after calving were $<1.0 \mathrm{mmol} / \mathrm{L}$ for hypocalcemic cows and $\geq 1$ $\mathrm{mmol} / \mathrm{L}$ for normocalcemic cows. 


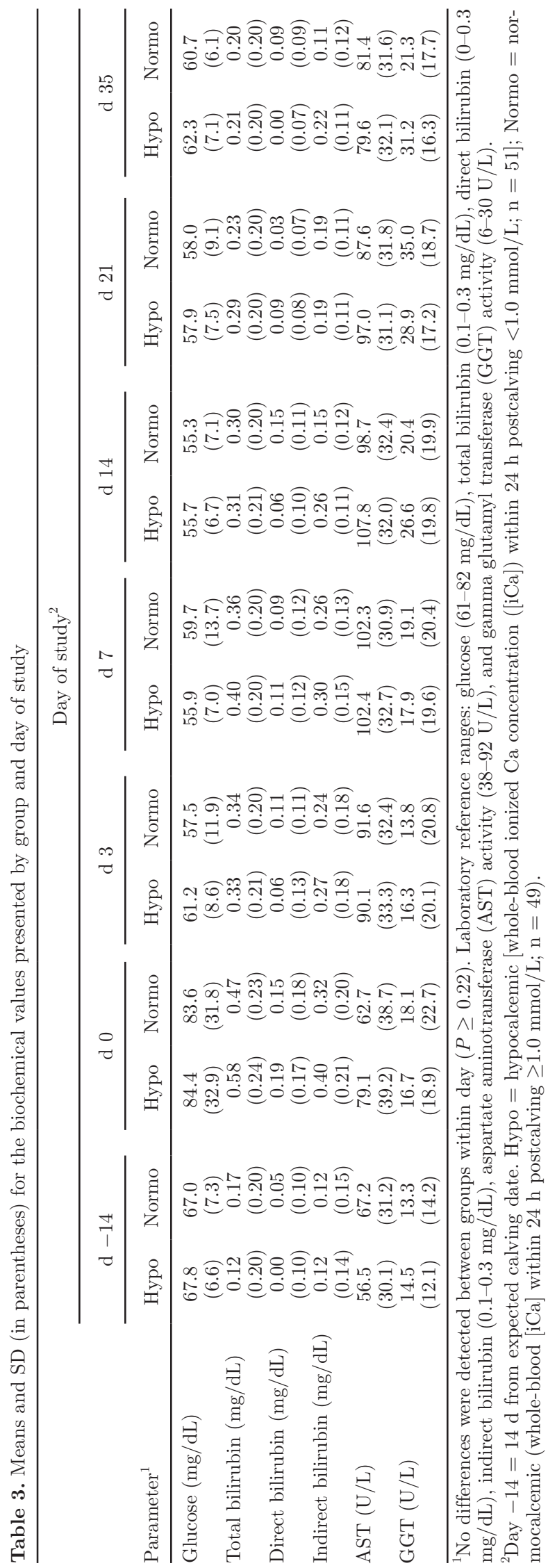

Stepwise regression to compare blood [iCa] on the day of calving with plasma NEFA concentration, liver lipid percentage, and plasma indirect bilirubin concentration revealed that the only variables significantly associated with d 0 [iCa] were plasma NEFA concentration at 14 $\mathrm{d}$ from expected calving date $\left(P=0.03 ; \mathrm{R}^{2}=0.05\right)$ and on the day of calving $\left(P=0.02 ; \mathrm{R}^{2}=0.06\right)$. None of these variables were significantly associated with plasma total Ca concentration $(P \geq 0.06)$.

Stepwise regression was performed to compare plasma NEFA concentration relative with liver lipid percentage on the days liver biopsy specimens were collected (d 0, 7, and 35). Liver lipid percentage on the day of calving (d 0) was associated with plasma NEFA concentrations on $\mathrm{d}-14\left(P<0.01 ; \mathrm{R}^{2}=0.08\right), 7(P=$ $\left.0.03 ; \mathrm{R}^{2}=0.17\right)$, and $21\left(P<0.01 ; \mathrm{R}^{2}=0.19\right)$. Liver lipid percentage on $\mathrm{d} 7$ postpartum was associated with plasma NEFA concentration on d $3\left(P<0.01 ; \mathrm{R}^{2}=\right.$ 0.24 ). Liver lipid percentage on d 35 postpartum was significantly associated with plasma NEFA concentration $14 \mathrm{~d}$ from expected calving date $\left(P<0.01 ; \mathrm{R}^{2}=\right.$ $0.54)$. It was also found with stepwise regression that plasma NEFA concentration at $14 \mathrm{~d}$ from expected calving date $\left(P=0.03 ; \mathrm{R}^{2}=0.03\right)$ and on the day of calving $\left(P<0.01 ; \mathrm{R}^{2}=0.65\right)$ were significantly correlated with plasma unconjugated bilirubin concentration on the day of calving.

\section{DISCUSSION}

Dairy cows experience subclinical hypocalcemia when whole-blood total $\mathrm{Ca}$ is less than $2.0 \mathrm{mmol} / \mathrm{L}$ or 8.0 $\mathrm{mg} / \mathrm{dL}$ (Goff, 2008). As approximately half of total Ca is ionized (Ballantine and Herbein, 1991), $1.0 \mathrm{mmol} / \mathrm{L}$ was chosen as the threshold to differentiate subclinical hypocalcemia from normocalcemia. Possible disadvantages exist to this approach for differentiating hypocalcemic cows from normocalcemic cows. Physiologically, cows just above and just below this threshold may be no different from each other. For this reason, regression analysis was also performed on the data to evaluate energy metabolism over a range of Ca concentrations.

In the present study, $51 \%$ of cows experienced subclinical hypocalcemia, which is similar to the observations made by Horst et al. (2003) and Reinhardt et al. (2011), who reported that, on average, approximately $50 \%$ of mature dairy cows will experience subclinical hypocalcemia at calving. In the current study, hypocalcemic cows recovered to the same blood iCa level as normocalcemic cows by d 3 postpartum, as previously described (Goff and Horst, 1997a; Moore et al., 2000; Goff et al., 2002).

For the first 3 mo of the study, the dry cows were inadvertently fed a vitamin and mineral premix designed 
Table 4. Proportions (no./total no., with percentages in parentheses) of cattle with a given postpartum disorder according to group

\begin{tabular}{|c|c|c|c|}
\hline Disorder & Hypocalcemic $^{1}$ & Normocalcemic $^{2}$ & $P$-value \\
\hline Clinical mastitis & $5 / 51(10)$ & $5 / 49(10)$ & 0.95 \\
\hline Dystocia & $10 / 51(20)$ & $16 / 49(33)$ & 0.14 \\
\hline Metritis & $3 / 51(6)$ & $5 / 49(10)$ & 0.44 \\
\hline Retained placenta & $5 / 51(10)$ & $2 / 49(4)$ & 0.28 \\
\hline Displaced abomasum & $3 / 51(6)$ & $3 / 49(6)$ & 0.96 \\
\hline Ketosis & $25 / 51(49)$ & $23 / 49(45)$ & 0.80 \\
\hline
\end{tabular}

for lactating cows, which may have biased the results, as there were more hypocalcemic than normocalcemic cows during that time period. The reported positive DCAD for both dry cow diets (Table 1) indicate that both diets had the potential to increase the risk of hypocalcemia. Although the DCAD was less positive in the diet containing the lactating cow premix, the dietary Ca concentration was higher (Table 1), potentially influencing the ratio of hypocalcemic to normocalcemic cows in the first 3 mo of the study. Considering each diet's Ca content and DCAD together using the model (LT1) described by Lean et al. (2006), the predicted occurrence of milk fever for the group of cows inadvertently fed the lactating cow premix would have been $11.6 \%$, whereas the predicted occurrence of milk fever for the remainder of the cows fed the dry cow premix would have been $9.0 \%$. As only 1 case of clinical milk fever was diagnosed in the 1 cow not enrolled in the study, the model was not predictive of actual milk fever occurrence in the studied herd. However, the model of Lean et al. (2006) was not designed to predict the occurrence of subclinical hypocalcemia, which is what was being studied herein. The calculations do, however, provide some evidence as to why more cattle had subclinical hypocalcemia during the first 3 mo of the study before the ration was modified. After the ration was corrected, a more appropriate ratio of hypocalcemic to normocalcemic cows was noted. Regardless, blocking the cows should have reduced the variation associated with the diet premix error and minimized any influence on the results. There were 34 incomplete blocks, consisting of 1 cow per block because cows either did not match up due to parity or their calving dates were too far apart. Of the 34 cows, 18 were hypocalcemic (9 cows during the first $3 \mathrm{mo}$ ) and 16 were normocalcemic; thus, a relatively even distribution of hypocalcemic and normocalcemic cows minimized the bias.

Fourteen days from expected calving date, cows were metabolically similar based on measured plasma biochemical parameters. Because no measurements were made between $14 \mathrm{~d}$ from expected calving date and calving, it was not possible to determine whether differences occurred between groups in the intervening period.

Hypocalcemic cows had a maximum plasma NEFA concentration on the day of calving, whereas normocalcemic cows experienced peak plasma NEFA concentrations at $3 \mathrm{~d}$ postpartum. Previous studies have shown that plasma NEFA concentrations begin to increase anywhere from the last 2 wk of gestation (Weber et al., 2013) to the last 2 to 3 d (LeBlanc et al., 2005) before parturition. However, a great deal of variation exists in how much plasma NEFA concentrations rise around the time of parturition, with some cows being able to maintain DMI, mobilize less fat, and have the least negative energy balance postpartum relative to

Table 5. Reproductive parameters according to group

\begin{tabular}{lccc}
\hline $\begin{array}{l}\text { Reproductive } \\
\text { parameter }\end{array}$ & $\begin{array}{c}\text { Hypocalcemic } \\
(\mathrm{n}=47)\end{array}$ & $\begin{array}{c}\text { Normocalcemic } \\
(\mathrm{n}=43)\end{array}$ & $P$-value \\
\hline Cyclicity $^{3}$ & $27 / 47(57.4)$ & $27 / 43(62.8)$ & 0.36 \\
Services per conception $^{4}$ & $2.6 \pm 1.7$ & $2.4 \pm 1.2$ & 0.72 \\
Days open $^{4}$ & $127.6 \pm 63.3$ & $122.0 \pm 48.7$ & 0.67 \\
\hline
\end{tabular}

${ }^{1}$ Hypocalcemia was defined as whole-blood ionized Ca concentration $([\mathrm{iCa}])<1.0 \mathrm{mmol} / \mathrm{L}$ within $24 \mathrm{~h}$ after calving.

${ }^{2}$ Normocalcemia was defined as whole-blood $[\mathrm{iCa}] \geq 1.0 \mathrm{mmol} / \mathrm{L}$ within $24 \mathrm{~h}$ after calving.

${ }^{3}$ The number of cows with a corpus luteum was determined by transrectal ultrasonography at 50 to $60 \mathrm{~d}$ postpartum. Values are no./total no., with percentages in parentheses.

${ }^{4}$ Mean $\pm \mathrm{SD}$ 
other cows (Weber et al., 2013). Recent work has linked cow genetic merit for milk production to differences in lipid metabolism and, thus, lipid metabolism during the transition period seems to be not only a function of diet and feed intake, but also genotype (Khan et al., 2013; Rocco and McNamara, 2013). Peak plasma NEFA concentrations occur around the time of calving, with a gradual decline as feed intake increases after calving (Grummer, 1993; Ingvartsen and Andersen, 2000; LeBlanc et al., 2005). Blood NEFA concentrations have been used as an estimate of energy balance (Kunz et al., 1985). Based on the data presented herein, hypocalcemic cows appeared to experience a more severe negative energy balance on the day of calving.

The relationship between subclinical hypocalcemia at calving and plasma NEFA concentrations in the present study is similar to that found in previous reports (Horst et al., 2003; Spain et al., 2004; Reinhardt et al., 2011). This relationship may be explained by findings in humans where adipocytes stimulated with Casensing receptor agonists had decreased basal lipolysis (Cifuentes and Rojas, 2008) suggesting that lipolysis may increase with $\mathrm{Ca}$ depletion. Additionally, $\mathrm{Ca}$ is an important second messenger for energy metabolism in hepatocytes. It has been shown that increases in cytosolic $\mathrm{Ca}$ concentration lead to parallel increases in the concentration of $\mathrm{Ca}$ in mitochondria, and that this is important for the stimulation of mitochondrial oxidative metabolism (Hajnóczky et al., 1995). Calcium flux into the mitochondria phosphorylates pyruvate dehydrogenase to its active form (Denton et al., 1972), which converts pyruvate to acetyl CoA for entry into the tricarboxylic acid cycle. This also causes an increase in NADH, which is responsible for donating electrons during oxidative phosphorylation (Robb-Gaspers et al., 1998). Hence, alterations in plasma [iCa] could influence hepatocellular Ca concentrations and, thus, pyruvate dehydrogenase may not be activated as efficiently due to insufficient intracellular Ca. As a result, carbohydrate metabolism via the tricarboxylic acid cycle would be decreased, resulting in a more severe negative energy balance.

Subclinical hypocalcemia could conceivably result in decreased DMI as previously suggested by Goff and Horst (1997b). However, recent research indicates that cows with subclinical hypocalcemia actually had increased DMI in the last 2 wk prepartum and no differences were observed in postpartum DMI when compared with normocalcemic cows (Jawor et al., 2012).

Aslan et al. (1988) defined the severity of fatty liver disease based on the percentage of liver tissue infiltrated, with lipid percentage of 0 to $10 \%$ being mild, 10 to $20 \%$ moderate, and $>20 \%$ severe. This was based on correlating liver lipid infiltration with clinical signs such as anorexia, decreased milk production, and progressive debilitation, as well as hematologic changes such as decreased albumin and cholesterol (Sevinç et al., 2003). Based on the liver lipid criteria of Aslan et al. (1988), all biopsied cows in the present study, on average, were experiencing mild hepatic lipidosis on the day of calving (Figure 3). All biopsied cattle had a mean liver lipid percentage similar to that reported by Djoković et al. (2007), who noted that apparently healthy cattle had $8 \%$ liver lipid on the day of calving. By d 7 postpartum, hypocalcemic cows in the present study had severe hepatic lipidosis, whereas the normocalcemic cows had moderate hepatic lipidosis. Finally, by 35 d postpartum, the hypocalcemic cows were still in the moderate to severe range, whereas the normocalcemic cows were in the mild range. These data, in conjunction with the finding that hypocalcemic cattle had higher plasma NEFA concentrations on the day of calving, suggest that hypocalcemic cattle mobilized more lipid into their liver during the first week of lactation, which affected their liver lipid content on $d 35$. Figure 3 shows that the relative decline in liver lipid content between $d 7$ and 35 was similar between groups, but hypocalcemic cows had a proportionately higher liver lipid content at $\mathrm{d} 7$, which persisted to d 35 .

The lack of a detectable difference in milk yield between groups could indicate that the negative energy balance as measured by greater plasma NEFA concentrations and greater hepatic lipid infiltration was not of sufficient magnitude to affect milk production. Alternatively, this may indicate that the genetic potential of the hypocalcemic cows was not being reached. Hypocalcemic cows may be attempting to produce more milk than normocalcemic cows and, as a result, have lower blood $\mathrm{Ca}$ and higher plasma NEFA concentrations. Curtis et al., (1984) showed that cows with higher milk production potential were at greater risk of developing milk fever, but Ostergaard and Larsen (2000) noted that blood $\mathrm{Ca}$ at calving did not affect FCM yield. Although McNamara and Hillers (1986) showed that cows with higher genetic merit for milk production mobilize more fat in early lactation, their study did not evaluate the influence of Ca status. More recently, Khan et al. (2013) showed that basal and stimulated lipolysis were greater in high-genetic-merit cows at 7 DIM; however, by 28 DIM, no differences were observed when compared with low-genetic-merit cows. It is also possible that the milk production measures used in the present study (peak test-day milk yield and 305-d mature-equivalent $4 \% \mathrm{FCM}$ ) were not sensitive enough to detect subtle differences in production during early lactation.

Based on the results of stepwise regression, plasma NEFA concentration explained a significant amount 
of the variation in liver lipid content. As hypocalcemic cows had greater plasma NEFA concentrations than normocalcemic cows on $\mathrm{d}$ 0, this relationship may explain why hypocalcemic cows also had greater liver lipid percentage on $\mathrm{d} 7$ and 35 compared with normocalcemic cows. Alternatively, a difference may exist in liver lipid metabolism, resulting in decreased lipid clearance by hypocalcemic cows relative to normocalcemic cows. The significant associations between plasma NEFA concentration and liver lipid percentage observed in this study can be explained by the fact that as plasma NEFA concentrations increase, the ability of the liver to $\beta$-oxidize and export triglycerides can become overwhelmed and triglycerides are stored directly in hepatocytes (Hayirli, 2006). However, it was also noted in the present study that the lipid infiltration on the day of calving was associated with higher plasma NEFA concentrations on d 21 postpartum. If there is greater liver lipid infiltration on $\mathrm{d} 0$, the liver's function may be compromised to a point that worsens the negative energy balance, thus increasing plasma NEFA concentrations in an attempt to maintain milk production while further decreasing liver function. On 2 of the $3 \mathrm{~d}$ (d 0 and 35$)$ that liver biopsies were taken, a significant association was observed between the prepartum plasma NEFA concentration $(\mathrm{d}-14)$ and liver lipid percentage. This was similar to the trend noted by Bertics et al. (1992) who noted that prepartum blood NEFA concentrations were related to postpartum liver lipid infiltration.

When lipolysis results in increased plasma NEFA concentrations, the NEFA compete with bilirubin for uptake into hepatocytes to be metabolized (Reid et al., 1979). This may explain the strong association noted between these 2 parameters in the current study.

Djoković et al. (2007) stated that the correlation coefficient between liver lipid percentage and blood glucose concentration was -0.69 , indicating a moderate negative association. These data suggest that more severe lipid infiltration could impair the liver's gluconeogenic capacity, as also suggested by Rukkwamsuk et al. (1999). The results of the present study showed a similar relationship between liver lipid infiltration and blood glucose $(\mathrm{r}=-0.27)$. As the amount of lipid deposition increases in the liver, more hepatocellular damage can occur (Van den Top et al., 1996), which may explain the overall associations between plasma NEFA concentration and AST and GGT activities as well as liver lipid percentage and AST activity in the present study. As increased plasma NEFA concentrations result in increased liver lipid deposition, AST activity can be indirectly increased by elevated plasma NEFA concentrations. However, changes in plasma AST activity can also be associated with cardiac and skeletal muscle injury, so the health of these cells may account for some of the variation in AST activity, as plasma NEFA concentration and liver lipid percentage accounted for little of the variation in plasma AST activity in the current study (7 and 17\%, respectively). Increased plasma NEFA concentrations may also indirectly cause increased GGT activity because, as NEFA increases, hepatocellular lipid deposition increases, which may lead to an obstructive cholestasis (Cebra et al., 1997). Despite evidence of alterations in energy balance, plasma NEFA concentrations, and liver lipid content in hypocalcemic cattle, the occurrence of clinical ketosis as defined by elevated ketone levels in urine did not differ between groups in the present study (Table 4).

The postpartum diseases evaluated in this study were chosen because they have commonly been associated with hypocalcemia in dairy cattle in the literature (Curtis et al., 1983; Goff and Horst 1997b; Mulligan et al., 2006). Hypocalcemia may predispose a cow to displaced abomasum due to abomasal atony and gas accumulation (Madison and Troutt, 1988; Doll et al., 2009). Massey et al. (1993) reported that subclinical hypocalcemia was a significant risk factor for development of displaced abomasum. More recently, Seifi et al. (2011) and Chapinal et al., (2011) showed that cows with total blood Ca concentrations $\leq 2.3$ and $\leq 2.2$ $\mathrm{mmol} / \mathrm{L}$, respectively, at any time within the first week postpartum were 5 and 3 times, respectively, more likely to have a displaced abomasum than cows above these thresholds. Results of the present study showed that subclinical hypocalcemia was not associated with an increased occurrence of abomasal displacement. However, the present study had relatively few cows that developed abomasal displacement, which may have affected study power. Data from the present study do, however, agree with LeBlanc et al. (2005), who studied a much larger population of cattle and showed that serum Ca concentrations within 1 wk of calving were not significantly associated with risk of developing displaced abomasum.

Hypocalcemia has been shown to cause immunosuppression by depleting intracellular $\mathrm{Ca}$ stores in peripheral blood mononuclear cells (Kimura et al., 2006), which logically may affect disease prevalence in hypocalcemic cattle. Furthermore, hypocalcemia may decrease smooth muscle tone, thereby affecting the teat sphincter and myometrium. Hence, hypocalcemic cattle have the potential for an increased risk of mastitis, dystocia, retained placenta, and metritis (Goff and Horst, 1997b). Curtis et al. (1983) showed that cows with clinical milk fever were 3 times more likely to develop retained placentas and 8 times more likely to develop mastitis. Additionally, Martinez et al. (2012) reported that cows with subclinical hypocalcemia were at greater 
risk of developing metritis. Dystocia, retained placenta, and metritis are all reported to negatively affect fertility (Maizon et al., 2004), and Roche (2006) and Martinez et al. (2012) reported that clinical hypocalcemia is a significant risk factor for decreased conception and pregnancy rates. In the present study, there were no detectable increases in the occurrence of clinical mastitis, dystocia, retained placenta, or metritis associated with subclinical hypocalcemia. Likewise, no differences were found between groups with regard to cyclicity, services per conception, or days open. Although potential for error existed in milker-defined cases of clinical mastitis, milkers were blind to group assignment and hence any diagnostic error should have been distributed evenly between groups. Therefore, this should not have affected the results. During the current study, retained placenta was defined as a placenta that was not expelled within $12 \mathrm{~h}$ after parturition. Although previous studies define retained placenta as retention for greater than 12 or 24 h (Kay, 1978; Lin et al., 1989; Kelton et al., 1998), $95 \%$ of cows expelling the placenta within $24 \mathrm{~h}$ had already expelled their placenta at $12 \mathrm{~h}$ postpartum in another study (van Werven et al., 1992). Because the present study used the more conservative definition, it was more likely that a cow would be defined as having a retained placenta than if the 24 -h definition had been used.

\section{CONCLUSIONS}

These data indicate that subclinical hypocalcemia may be associated with alterations in lipid metabolism, as indicated by increased plasma NEFA concentrations at calving and increased lipid deposition in the liver at 7 and 35 DIM in the hypocalcemic group. Furthermore, plasma [iCa] at calving was associated with plasma NEFA concentrations on $\mathrm{d}-14$ and 0 , and liver lipid content on the day of calving was associated with plasma NEFA concentrations on $\mathrm{d}-14,7$, and 21 . Liver lipid content on d 7 was associated with plasma NEFA concentrations on d 3, and liver lipid content on d 35 was associated with plasma NEFA concentrations on d -14 . Hence, the degree of liver tissue infiltrated with lipid was generally associated with preceding elevations in plasma NEFA concentrations. This was also reflected in plasma unconjugated bilirubin concentrations on the day of calving, which were associated with plasma NEFA concentrations on $d-14$. Despite these findings, however, subclinical hypocalcemia was not associated with alterations in peak milk yield, 305-d 4\% FCM production, milk fat percentage, SNF percentage, SCC, or fertility measures. A plausible explanation for the lower milk protein in hypocalcemic cows on $\mathrm{d} 21$ and 35 postpartum was not determined. The occurrence of common postpartum disorders (ketosis, displaced abomasum, mastitis, dystocia, retained placenta, and metritis) that have been associated with negative energy balance and hypocalcemia likewise did not differ between groups. Because the genetic merit for milk production was not evaluated as a co-factor with $\mathrm{Ca}$ status at calving, the role of the cow genetic merit for milk production on Ca status and possible associations with lipid metabolism and postpartum health could not be ascertained.

\section{ACKNOWLEDGMENTS}

This work was funded by a grant from the University of Missouri, College of Veterinary Medicine, Agricultural Experiment Station (Columbia). The authors thank the following members of the University of Missouri staff, Julie Holle (Veterinary Medical Teaching Hospital), Howard Wilson (College of Veterinary Medicine, retired), John Denbigh and Eric Adkins (Foremost Dairy), and the following former University of Missouri students: Kari Chamberlin, Amanda Miller, Katie O'Brien, Laura Tadelski, Spencer Thompson, and Ben Nielsen for technical assistance.

\section{REFERENCES}

Aslan, V., R. Aştı, M. Nizamlığlu, T. Tekeli, A. Başoğlu, and U. Demirci. 1988. Fatty liver syndrome associated with some postparturient period disease. Selçuk Üniversitesi Veteriner Fakültesi Dergisi $4: 43-52$.

Ballantine, H. T., and J. H. Herbein. 1991. Potentiometric determination of ionized and total calcium in blood plasma of Holstein and Jersey cows. J. Dairy Sci. 74:446-449.

Bell, A. W. 1995. Regulation of organic nutrient metabolism during transition from late pregnancy to early lactation. J. Anim. Sci. 73:2804-2819.

Bertics, S. J., R. R. Grummer, C. Cadorniga-Valino, and E. E. Stoddard. 1992. Effect of prepartum dry matter intake on liver triglyceride concentration and early lactation. J. Dairy Sci. 75:19141922.

Cebra, C. K., F. B. Garry, D. M. Getzy, and M. J. Fettman. 1997. Hepatic lipidosis in anorectic, lactating Holstein cattle: A retrospective study of serum biochemical abnormalities. J. Vet. Intern. Med. 11:231-237.

Chapinal, N., M. Carson, T. F. Duffield, M. Capel, S. Godden, M. Overton, J. E. P. Santos, and S. J. LeBlanc. 2011. The association of serum metabolites with clinical disease during the transition period. J. Dairy Sci. 94:4897-4903.

Cifuentes, M., and C. V. Rojas. 2008. Antilipolytic effect of calcium-sensing receptor in human adipocytes. Mol. Cell. Biochem. 319:17-21.

Conover, W. J., and R. L. Iman. 1981. Rank transformations as a bridge between parametric and nonparametric statistics. Am. Stat. 35:124-129.

Curtis, C. R., H. N. Erb, C. J. Sniffen, and R. D. Smith. 1984. Epidemiology of parturient paresis: Predisposing factors with emphasis on dry cow feeding and management. J. Dairy Sci. 67:817-825.

Curtis, C. R., H. N. Erb, C. J. Sniffen, R. D. Smith, P. A. Powers, M. C. Smith, M. E. White, R. B. Hillman, and E. J. Pearson. 1983. Association of parturient hypocalcemia with eight periparturient disorders in Holstein cows. J. Am. Vet. Med. Assoc. 183:559-561. 
Denton, R. M., P. J. Randle, and B. R. Martin. 1972. Stimulation by calcium ions of pyruvate dehydrogenase phosphate phosphatase. Biochem. J. 128:161-163.

Djoković, R., H. Šamanc, M. Jovanović, and Z. Nikolić. 2007. Blood concentrations of thyroid hormones and lipids and content of lipids in the liver of dairy cows in transitional period. Acta Vet. (Brno) $76: 525-532$.

Doll, K., M. Sickinger, and T. Seeger. 2009. New aspects in the pathogenesis of abomasal displacement. Vet. J. 181:90-96.

Duffield, T. F., K. D. Lissemore, B. W. McBride, and K. E. Leslie. 2009. Impact of hyperketonemia in early lactation dairy cows on health and production. J. Dairy Sci. 92:571-580.

Goff, J. P. 2006. Major advances in our understanding of nutritional influences on bovine health. J. Dairy Sci. 89:1292-1301.

Goff, J. P. 2008. The monitoring, prevention and treatment of milk fever and subclinical hypocalcemia in dairy cows. Vet. J. 176:50-57.

Goff, J. P., and R. L. Horst. 1997a. Effects of the addition of potassium or sodium, but not calcium, to prepartum rations on milk fever in dairy cows. J. Dairy Sci. 80:176-186.

Goff, J. P., and R. L. Horst. 1997b. Physiological changes at parturition and their relationship to metabolic disorders. J. Dairy Sci. 80:1260-1268

Goff, J. P., K. Kimura, and R. L. Horst. 2002. Effect of mastectomy on milk fever, energy, and vitamins $\mathrm{A}, \mathrm{E}$, and $\beta$-carotene status at parturition. J. Dairy Sci. 85:1427-1436.

Grummer, R. R. 1993. Etiology of lipid-related metabolic disorders in periparturient dairy cows. J. Dairy Sci. 76:3882-3896.

Grummer, R. R. 1995. Impact of changes in organic nutrient metabolism on feeding the transition dairy cow. J. Anim. Sci. 73:2820 2833

Hajnóczky, G., L. D. Robb-Gaspers, M. B. Seitz, and A. P. Thomas, 1995. Decoding of cytosolic calcium oscillations in the mitochondria. Cell 82:415-424.

Hayirli, A. 2006. The role of exogenous insulin in the complex of hepatic lipidosis and ketosis associated with insulin resistance phenomenon in postpartum dairy cattle. Vet. Res. Commun. 30:749-774.

Horst, R. L., J. P. Goff, and B. McCluskey. 2003. Prevalence of subclinical hypocalcemia in U.S. dairy operations. US Department of Agriculture (USDA) Agricultural Research Service, Washington, DC.

Hughes, J. P. 1962. A simplified instrument for obtaining liver biopsies in cattle. Am. J. Vet. Res. 23:1111-1113.

Ingvartsen, K. L., and J. B. Andersen. 2000. Integration of metabolism and intake regulation: A review focusing on periparturient animals. J. Dairy Sci. 83:1573-1597.

Jawor, P. E., J. M. Huzzey, S. J. LeBlanc, and M. A. G. von Keyserlingk. 2012. Associations of subclinical hypocalcemia at calving with milk yield, and feeding, drinking, and standing behaviors around parturition in Holstein cows. J. Dairy Sci. 95:1240-1248.

Johnson, M. M., and J. P. Peters. 1993. An improved method to quantify nonesterified fatty acids in bovine plasma. J. Anim. Sci. 71:753-756.

Kay, R. M. 1978. Changes in milk production, fertility and calf mortality associated with retained placenta or the birth of twins. Vet. Rec. 102:477-479.

Kelton, D. F., K. D. Lissemore, and R. E. Martin. 1998. Recommendations for recording and calculating the incidence of selected clinical diseases of dairy cattle. J. Dairy Sci. 81:2502-2509.

Khan, M. J., A. Hosseini, S. Burrell, S. M. Rocco, J. P. McNamara, and J. J. Loor. 2013. Change in subcutaneous adipose tissue metabolism and gene network expression during the transition period in dairy cows, including differences due to sire genetic merit. J. Dairy Sci. 96:2171-2182.

Kimura, K., T. A. Reinhardt, and J. P. Goff. 2006. Parturition and hypocalcemia blunts calcium signals in immune cells of dairy cattle. J. Dairy Sci. 89:2588-2595.

Kunz, P. L., J. W. Blum, I. C. Hart, H. Bickel, and J. Landis. 1985 Effects of different energy intakes before and after calving on food intake, performance and blood hormones and metabolites in dairy cows. Anim. Prod. 40:219-231.
Lean, I. J., P. J. DeGaris, D. M. McNeil, and E. Block. 2006. Hypocalcemia in dairy cows: Meta-analysis and dietary cation anion difference theory revisited. J. Dairy Sci. 89:669-684.

LeBlanc, S. J., T. H. Herdt, W. M. Seymour, T. F. Duffield, and K. E. Leslie. 2004. Factors associated with peripartum serum concentrations of vitamin $\mathrm{E}$, retinol, and $\beta$-carotene in Holstein dairy cattle, and their associations with periparturient disease. J. Dairy Sci. 87:609-619.

LeBlanc, S. J., K. E. Leslie, and T. F. Duffield. 2005. Metabolic predictors of displaced abomasum in dairy cattle. J. Dairy Sci $88: 159-170$.

Lin, H. K., P. A. Oltenacu, L. D. Van Vleck, H. N. Erb, and R. D. Smith. 1989. Heritabilities of and genetic correlation among six health problems in Holstein cows. J. Dairy Sci. 72:180-186.

Lombard, J. E., F. B. Garry, S. M. Tomlinson, and L. P. Garber. 2007. Impacts of dystocia on health and survival of dairy calves. J. Dairy Sci. 90:1751-1760.

Madison, J. B., and H. F. Troutt. 1988. Effects of hypocalcaemia on abomasal motility. Res. Vet. Sci. 44:264-266.

Maizon, D. O., P. A. Oltenacu, Y. T. Gröhn, R. L. Strawderman, and U. Emanuelson. 2004. Effects of diseases on reproductive performance in Swedish red and white dairy cattle. Prev. Vet. Med. 66:113-126.

Martinez, N., C. A. Risco, F. S. Lima, R. S. Bisinotto, L. F. Greco, E. S. Ribeiro, F. Maunsell, K. Galvão, and J. E. P. Santos. 2012 Evaluation of peripartal calcium status, energetic profile, and neutrophil function in dairy cows at low or high risk of developing uterine disease. J. Dairy Sci. 95:7158-7172.

Massey, C. D., C. Wang, G. A. Donovan, and D. K. Beede. 1993. Hypocalcemia at parturition as a risk factor for left displacement of the abomasum in dairy cows. J. Am. Vet. Med. Assoc. 203:852-853.

McLaren, C. J., K. D. Lissemore, T. F. Duffield, K. E. Leslie, D. F. Kelton, and B. Grexton. 2006. The relationship between herd level disease incidence and a return over feed index in Ontario dairy herds. Can. Vet. J. 47:767-773.

McNamara, J. P., and J. K. Hillers. 1986. Regulation of bovine adipose tissue metabolism during lactation. 2. Lipolysis response to milk production and energy intake. J. Dairy Sci. 69:3042-3050.

Moore, S. J., M. J. VandeHaar, B. K. Sharma, T. E. Pilbeam, D K. Beede, H. F. Bucholtz, J. S. Liesman, R. L. Horst, and J. P. Goff. 2000. Effects of altering dietary cation-anion difference on calcium and energy metabolism in peripartum cows. J. Dairy Sci 83:2095-2104.

Mulligan, F. J., L. O'Grady, D. A. Rice, and M. L. Doherty. 2006 A herd health approach to dairy cow nutrition and production diseases of the transition cow. Anim. Reprod. Sci. 96:331-353.

NRC. 2001. Nutrient Requirements of Dairy Cattle. 7th rev. ed. National Academies Press, Washington, DC

Østergaard, S., and T. Larsen. 2000. Associations between blood calcium status at calving and milk yield in dairy cows. J. Dairy Sci 83:2438-2440.

Peter, A. T., P. L. Vos, and D. J. Ambrose. 2009. Postpartum anestrus in dairy cattle. Theriogenology 71:1333-1342.

Reid, I. M., C. J. Roberts, and R. Manston. 1979. Reduced fertility associated with fatty liver in high yielding dairy cows. Vet. Sci. Commun. 3:231-236.

Reinhardt, T. A., J. D. Lippolis, B. J. McCluskey, J. P. Goff, and R. L. Horst. 2011. Prevalence of subclinical hypocalcemia in dairy herds. Vet. J. 188:122-124.

Robb-Gaspers, L. D., P. Burnett, G. A. Rutter, R. M. Denton, R. Rizzuto, and A. P. Thomas. 1998. Integrating cytosolic calcium signals into mitochondrial metabolic responses. EMBO J. 17:4987-5000.

Rocco, S. M., and J. P. McNamara. 2013. Regulation of bovine adipose tissue metabolism during lactation. 7. Metabolism and gene expression as a function of genetic merit and dietary energy intake. J. Dairy Sci. 96:3108-3119.

Roche, J. F. 2006. The effect of nutritional management of the dairy cow on reproductive efficiency. Anim. Reprod. Sci. 96:282-296. 
Rukkwamsuk, T., T. Wensing, and M. J. H. Geelen. 1999. Effect of fatty liver on hepatic gluconeogenesis in periparturient dairy cows. J. Dairy Sci. 82:500-505.

Seifi, H. A., S. J. LeBlanc, K. E. Leslie, and T. F. Duffield. 2011. Metabolic predictors of post-partum disease and culling risk in dairy cattle. Vet. J. 188:216-220.

Semecan, A., and M. Sevinç. 2005. Liver function in cows with retained placenta. Turk. J. Vet. Anim. Sci. 29:775-778.

Sevinç, M., A. Başoğlu, H. Güzelbektaş, and M. Boydak. 2003. Lipid and lipoprotein levels in dairy cows with fatty liver. Turk. J. Vet. Anim. Sci. 27:295-299.

Sheldon, I. M., G. S. Lewis, S. J. LeBlanc, and R. O. Gilbert. 2006. Defining postpartum uterine disease in cattle. Theriogenology 65:1516-1530.

Spain, J., R. Vogel, and J. D. Sampson. 2004. The effects of feeding supplemental anionic salt fed during the periparturient period: Implications of milk production and feed intake for high producing dairy cows. J. Dairy Sci. 87(Suppl. 1):345.

Van den Top, A. M., M. J. H. Geelen, T. Wensing, G. H. Wentink, A. T. Van 't Klooster, and C. Beynen. 1996. Higher postpartum he- patic triacylglycerol concentrations in dairy cows with free rather than restricted access to feed during the dry period are associated with lower activities of hepatic glycerolphosphate acyltransferase. J. Nutr. 126:76-85.

van Werven, T., Y. H. Schukken, J. Lloyd, A. Brand, H. T. Heeringa, and M. Shea. 1992. The effects of duration of retained placenta on reproduction, milk production, postpartum disease and culling rate. Theriogenology 37:1191-1203.

Walsh, R. B., D. F. Kelton, T. F. Duffield, K. E. Leslie, J. S. Walton, and S. J. LeBlanc. 2007. Prevalence and risk factors for postpartum anovulatory condition in dairy cows. J. Dairy Sci. 90:315-324.

Weber, C., C. Hametner, A. Tuchscherer, B. Losand, E. Kanitz, W. Otten, S. P. Singh, R. M. Bruckmaier, F. Becker, W. Kanitz, and H. M. Hammon. 2013. Variation in fat mobilization during early lactation differently affects feed intake, body condition, and lipid and glucose metabolism in high-yielding dairy cows. J. Dairy Sci. $96: 165-180$. 